УДК: 930=161.2(043)

DOI: https://doi.org/10.31470/2518-7600-2020-10-37-56

RUSSIAN FINANCIAL POLICY AND THE MONEY CIRCULATION OF OVER DNIPRO UKRAINE IN THE COLUMNS OF THE PRE-SOVIET PERIODICAL NEWSPAPERS: THE SOURCES STUDYING ASPECT

\title{
РОСІЙСЬКА ФІНАНСОВА ПОЛІТИКА ТА ГРОШОВИЙ ОБІГ НАДЛНІПРЯНСЫКОЇ УКРАЇНИ НА ШПАЛЬТАХ ДОРАДЯНСЬКОЇ ПЕРІОДИЧНОЇ ПРЕСИ: ДЖЕРЕЛОЗНАВЧИЙ АСПЕКТ
}

\section{РОССИЙСКАЯ ФИНАНСОВАЯ ПОЛИТИКА И ДЕНЕЖНОЕ ОБРАЩЕНИЕ НАДДНЕПРЯНСКОЙ УКРАИНЫ НА СТРАНИЦАХ ДОСОВЕТСКОЙ ПЕРИОДИЧЕСКОЙ ПРЕССЫ: ИСТОЧНИКОВЕДЧЕСКИЙ АСПЕКТ}

Андрій Бойко-Гагарін, кандидат історичних наук, завідувач сектору проблем фондової роботи e-mail:

boiko.gagarin@gmail.com ORCID 0000-0003-4610-3665

Національний музей історії України. вул. Володимирська, 2, м. Київ, 01001, Україна

Сергій Кулешов, доктор історичних наук, професор кафедри історії, археології, інформаційної та архівної справи e-mail: posena@ukr.net
Andrii Boiko-Gagarin, Ph.D. in historical science, head of the sector of the treasury problems e-mail:

boiko.gagarin@gmail.com ORCID 0000-0003-4610-3665 National Museum of History of Ukraine. Volodymyrska str. 2, Kyiv, 01001, Ukraine

Serhii G. Kuleshov, Doctor of History, (Dr. habil.) Professor of the Departament of Historica, Archeological, Information and Archival Affairs e-mail:posena@ukr.net 
ORCID 0000-0003-1950-9651

Центральноукраїнський

національний технічний

університет. пр.

Університетський, 8,

м. Кропивницький, 25006,

Україна
ORCID 0000-0003-1950-9651

Central Ukrainian National

Technical University.

Universytetski av. 8,

Kropyvnytskyi, 25006, Ukraine

\section{ABSTRACT}

The article analyzes the publications of the pages of the preSoviet newspapers periodicals of the different cities of Ukraine in order to establish the value of the newspaper notes as a source of study and to determine the effectiveness of their use in the studies of the history of money circulation and Russian imperian financial policy in Ukraine during the second half of XIX century until the collapse of the Russian Empire in 1917. During their existence, the newspapers were in fact the most only effective and widespread sources of achieving of the information, were serving as a communication tool between government and the public, providing an important information on a various priblems.

We have analyzed and given the most interesting examples from the newspaper publications related to various aspects of the money circulation. Examining the notes from the newspapers that were published on a regular basis in Ukrainian cities in the second half of XIX and the beginning of the XX centuries, we were able to establish the following main types of the newspaper press messages: the publications on the introduction of a new coins and banknotes; the notification of the exchange rates of Russian and foreign coins; the features of the circulation and the situation in the money market; the prices for goods and services on markets; the money laundering reports; the government measures to overcome financial difficulties: the "coin hunger» and speculation with money, etc.; on the purchase of antique coins, as well as collecting and deceiving collectors with antique coins; the professional scientific numismatic researches and formation about the museum numismatic 
collections; the procedure for exchanging non-payment banknotes and signs of their suitability; the money counterfeitings and other testimonies designed to evoke a variety of emotions in the reader. All of the introduced into scientific circulation newspaper messages and notes are significantly expanding our understanding of the peculiarities of the development of money circulation in Ukraine during the imperial period. The wide variety of testimonies concerning the money circulation placed in a newspaper reports allows us to determine the high efficiency of the use of newspaper periodical information in the study of the chosen topic, defining the newspapers as an effective and informative scientific source.

Keywords: Russian Empire, Over Dnipro part of Ukraine, money circulation, newspapers edition, sources of the study, financial policy.

Постановка проблеми. Використання ефективних джерел $\epsilon$ головною запорукою ефективного наукового дослідження та досягнення вагомого результату. Iз розсекреченням архівних фондів та полегшенням доступу дослідників до історичних джерел все більшої актуальності набира вивчення, аналіз та введення у науковий обіг вирішення проблем в історії України. Активного розвитку набуває також нумізматика, історія грошового обігу та інші спеціальні історичні дисципліни. Дослідниками високо оцінено монети та паперові грошові знаки як найбільш ефективні речові джерела вивчення історії грошового обігу, доповнюючи аналіз монет даними із архівів, законів тощо. Ступінь ефективності використання газет в дослідженні історії грошового обігу досі була досліджена спорадично.

Аналіз останніх досліджень і публікацій. Високу актуальність дослідження історії фінансів Російської імперії та України на той час в їі складі, якісно обгрунтовано в дослідженнях професора В. Орлика, визначивши стан і перспективи вичення історії фінансів першої половини ХІХ ст. (Орлик В., 2011-а: 96-108), приділяючи увагу також і окремим 
iї складовим: фіскальній (Орлик В., 2006: 97-110) та податковій (Орлик В., 2004: 224-239) політиці, використовуючи архівні матеріали (Орлик В., 2011-b: 98-110) та фінансово-павову літературу (Орлик В., 2010), визначаючи ефективну методологію досліджень (Орлик В., 2011-с: 59-64; Орлик В., Орлик С. 2019).

Метою статті $є$ визначення наукового потенціалу та значення матеріалів із газетних публікацій у фокусі дослідження історії та особливостей грошового обігу в Наддніпрянській Україні в другій пол. XIX - пер. чв. XX ст.

Виклад основного матеріалу. Газети досліджуваного періоду є надзвичайно цінним джерелом у науковому вивченні найрізноманітніших аспектів в історичних дослідженнях. Академіком В. Коцуром інформація зі шпальт газет введено до наукового обігу раніше невіомі знахідки монетних скарбів (Коцур, 2017: 15-32), наведено ціни із газетних джерел Чернігівщини поч. ХІХ ст. (Kotsur, Boiko-Gagarin, 2019: 66-77). Дослідником А. Бойко-Гагаріним широко використано матеріали дорадянських газет у фокусі досліджень окремих аспектів нумізматики та історії грошового обігу: введено до наукового обігу раніше неопубліковані свічення фальшування грошей в Російській (Бойко-Гагарин, 2016-а: 103-109; БойкоГагарін, 2018: 132-149) та Австро-Угорській імперіях (Бойко-Гагарін, 2019: 55-75), (високо оцінюючи також цінність газет як джерела), описуючи також надходження монет до музейних колекції (Бойко-Гагарін, 2016-b: 134-145).

В статті ми проводимо аналіз матеріалів з періодичної преси, що видавалась в різних містах Російської імперії для встановлення цінності газетних заміток та ефективності їх використання у вивченні історії грошового обігу в Наддніпрянській Україні з другої пол. ХХ ст. до часу розвалу Російської імперії.

У час свого побутування газети були практично єдиним ефективним та популярним джерелом отримання інформації, слугуючи комунікативним інструментом між населенням 
регіонів та місцевої та імперської влади, надаючи населенню важливу інформацію з найрізноманітніших аспектів.

Наведемо та проаналізуємо найцікавіші приклади із вказаних напрямків інформування газетами про ті чи інші особливості грошового обігу. В першу чергу слід вказати на такий важливий вид повідомлень як інформування про введення нових грошей, що відбувалось із наведенням їх опису та особливостей захисту від підробок. Відповідно, окрім ввдення нових монет, газети також інформували i про припинення обміну чи обігу грошей. Так газета «Южанин», що видавалась у Моколаїві, від 17 грудня 1898 р. повідомляє про емісію нових крелитних білетів 500 руб. номіналу із портретом імператора Петра I, вказуючи на значний обсяг емісії цих знаків (200.000 екземплярів), а також очікування їх в грошовому обігу в березні наступного 1899 р. (Южанин, 1898: 2). В газетах також можна зустріти інформацію про введення нових грошей за межами Російської імперії - так, київська «Вечерняя Газета» повідомляє 17 травня 1916 р. про введення нових грошей у таборах військовополонених у ворогуючій Австро-Угорщині: «У Австрії, в таборах для військовополонених, введено особливу монету із заліза для дрібних одиниць та із олова - для більш значимих сум. Така монета має платіжну здатність лише для кожного окремого табору» (Вечерняя Газета, 1916-а: 4). Із погіршенням фінансового стану Російської імперії внаслідок надзвичайних витрат на війну, з грошового обігу зникає дрібна ромінна монета, будучи тезаврованою населенням (Орлик, 2015: 114-133), що викликає занепокоєння та необхідність вирішення питання з виникненням «монетного голоду» з боку влади (Орлик, 2017: 141-148). Ледь не найбільш актуальну проблему для населення в часи Першої Світової війни не могли лишити поза увагою тогочасні газети. Відповідно до ситуації, що виникла на грошовому ринку, газета «Вечерние Газета» цитує офіційний коментар Д.І. Нікіфоровим щодо планів введення міністерством Фінансів монет із дорогоцінних металів: «...Міністерство фінанів застосує подібний захід лише 
тоді, коли буде впевненим в тому, що наявних запасів монети вистачить надовго та до випуску паперових знаків повертатись не прийдеться..» (Вечерняя Газета, 1916-b: 2). Також із коментаря в замітці згадано про численні негативні соціальні настрої через нестачу монети, спекуляції, махінації та введення в оману, непідтверджених чуток тощо. Дані щодо введення нових грошей інколи супроводжуються графічними зображеннями, так «Одесские Новости» публікує абрис нових банкнот Франції, введених заміть обігових монет у 1914 р. (Одесские новости, 1914: 2) (Рис. 1).

Газетні колонки також висвітлюють і інші особливості, що складались навколо застосування в процесі роздрібної торгівлі та угод 3 використанням готівкових грошей. Iз настанням «монетного голоду» виникали махінації навколо викупу золотих монет, так «Вечерняя Газета» повідомляє про спроби вимінювання в віддалених від крупних населених пунктів у довірливого населення - золотих монет, поширюючи неправдиві свідчення про їх заборону після війни та потенційні покарання тих, хто нею володіє (Вечерняя Газета, 1916-с: 4). Складнощі відчувались і з дрібною розмінною монетою та нестачею їі для видачі решти. Так у 1916 році в Одесі набула відчутною нестача розмінних монет номіналом пів копійки, коли із подорожчанням спирту на $1 \frac{1}{2}$ коп. і при його новій ціні в 241/2 коп. стала відчутною незручність у поверненні 1/2 коп. решти (Маленькие Одесские новости, 1916-а: 4).

Із введенням в обіг раніше мало характерного явища як пам'ятні, або коммеморативні обігові монети номіналом в 1 та 11/2 руб. (Екатеринославскийй листок, 1883: 3), попит на бажання їх оримати зростав. Це викликало застосування деякими торговими фірмами своєрідного маркетингового ходу як закликання покупців до вибору саме конкретного магазину, обіцяючи надання в решту новими рублями, карбованих в честь коронації Миколи II (Новороссийский Телеграф, 1886: 4).

Повідомлення на шпальтах газет також відображають свідчення і про загальний стан фінансів в тій чи іній місцевості, 
характеризуючи ситуацію з грошовим ринком, станом торгівлі, а також публікуючи актуальні ціни на ринках регіону для запобігання невиправданї дорожнечі.

Для сприяння розвитку торгівлі та підвищення цікавості і користі від купівлі газет багатьма друкованими виданнями публікуються обмінні курси іноземних обігових монет по відношенню до російських. 22 березня 1891 р. газета «Елисаветградский Вестник» публікує актуальні курси золотих півімперіалів старого зразка до нових срібних рублів а також співвідношення щодо них французьких наполеондорів, британських фунтів стерлінгів, турецької ліри та золотих та срібних флоринів Австро-Угорщини (Елисаветградскийй Вестник, 1891: 4).

17 травня 1870 р. київська газета «Друг Народа» наводить дані про актуальні ціни та товари на ринках міста, оцінюючи пуд ржаного борошна у 55 коп., пшона - 75 коп., печеного хліба - 50 коп., коров'ячого масла - 14 коп. за фунт, олії - 30 коп. за фунт, свине сало - 15 коп. за фунт, курка 35 коп., гуска 1 руб., качка 30 коп., порося 1 руб., яловичина першого гатунку по 7 коп. за фунт, а також сіно по 23 коп за пуд (Друг Народа, 1870: 320). Перша Світова війна призвела до продовольчої кризи, введенню продуктових карток та непомірної дорожнечі. 25 травня 1915 р., на другий рік війни, проскурівська газета «Земская Мысль» повідомляє про фіксовані ціни, встановлені земством, визначаючи: овес $-1,20$ руб. за пуд; сіно - 40 коп. за пуд; борошно пшеничне - 2,60 руб. за пуд; борошно кукурудзяне - 1,20 руб. за пуд; крупа гречнева $-2,30$ руб. за пуд; рис - 13 коп. за фунт; горох - 3 коп. за фунт; квасоля $-1,60$ руб. за пуд, або 4 коп. за фунт; сіль столова - 90 коп. за пуд; масло коров'яче - 40 коп. за фунт; цибуля - 2,50 руб. за пуд; картопя - 20 коп. за пуд; капуста свіжа - 40 коп. за пуд; цукор пісок - 11 коп. за фунт; міло для білизни - 6 руб. за пуд; яйця 1,5 руб. за 100 од.; дрова пиляні - 15 коп. за пуд; вугілля антрицат - 40 коп. за пуд; м'ясо яловиче - 13 коп. за фунт, керосин - 2,25 руб. за пуд., при цьому сама досліджена газета коштувала 3 коп. (Земская Мысль, 1915: 4). 
Тогочасні газети не рідко повідомляють і про колекційну складову нумізматики. Так 28 березня 1906 р. газета «Киевская Заря» публікує повідомлення магазину антиквара із Тули - I.B. Мігунова, що тимчасово на термін в 1 місяць відкрив крамницю антикваріату в Києві на вул. Хрещатик (Рис. 2) (Кивеская Заря, 1906: 6). Бажання придбати старовинні монетні рідкості супроводжувалось і спробами шахрайства: газета «Житомирская минута» у цілих двох повідомленнях розповідає про обман власника бакалійної крамниці на прізвище Грідін невідомими особами що запропонували йому сфабрикований давній скарб золотих монет, що виявились старими мідними обіговими монетами, зістареними під золото (Житомирская минута, 1908-а: 2). Після викриття обману новий власник зі злоби зпалив разом із дерев'яною скринею, в якій їх ніби то було найдено (Житомирская минута, 1908-b: 2). У 1915 р. газета «Черниговское Слово» повідомляє про випадок із колекціонером поміщиком М.Є. Карповським, в якого під час його від’їзду було викрадено із столу скриньку із колекцією монет (Черниговское Слово, 1915: 3).

Інформують замітки в періодиці i про формування музейних колекцій та наукові досілдеження професійними нумізматами в Російській імперії. Газета «Киевский Телеграф» надає розгорнуті коментарі щодо діяльностіі головного хранителя нумізматичної колекції Університету Св. Володимира - Якова Волошинського, підводячи підсумки за минулий 1861 р., повідомляючи про дослідження хранителем колекції київської палати державного майна (московська та іноземна монета XVII ст.), поміщика Д.А. Трощинського (більше 3000 античних монет Риму та Греції) та чиновника Дергимана (5000 монет різного часу), детально описуючи склад їх зібрань (Киевский Телеграф, 1862: 569).

Із часом будь-які знаки грошової оплати зношуються, псуються, піддаються забрудненню та пошкодженням, після чого виводяться із грошової маси. Так київська газета «Труд» публікує найвищу постанову російської влади про порядок 
обміну кредитних білетів із пошкодженнями, деально описуючи щодо платіжної спроможності грошей. Так, при збереженні більше 2/3 поля банкнот 25 руб. номіналу, натомість розірваний навпіл кредитний білет може бути прийнятий державним банком при повній відповідності номерів та серій 3 обох його сторін та чіткому спів падінні місця його розриву по зображенню малюнку (Труд, 1881: 3). Пошкоджені від вогню кредитні білети можуть бути прийняті банком в обмін в разі надіслання окремого клопотання про їх обмін в відділення Державного Банку у Петербург (Маленькие Одесские новости, 1916-b: 5).

В газетних повідомленнях часів Російської імперії можна зустріти і досить незвичні повідомлення, поява яких викликана, скоріше за все, бажанням редакторів газет привабити увагу пересічного читача, вчиняючи спроби його здивування чи викликання емоцій від незвичної інформації.

29 листопада 1883 р. газета «Николаевский Листок» повідомляє про накопичення в державних казначействах такої велетенської кількості обігових монет старого зразка, що лише для доставлення всієї їх маси до монетного двору для переплавлення необхідно витратити близько 65000 руб. (Николаевский Листок, 1883: 472-473). Інформування населення про сильну забрудненість засобів платежу та наявність численної кількості батерій на монетах були на стільки популярними, що нам вдалось відшукати декілька таких повідомлень в двох різних газетах. У 1884 р. в газеті «Николаевский вестник» повідомлялось про випадкові досліди професора на прізвище Рейнш, що досліджуючи обігову 50 пфенігову монету під мікроскопом при 200 та 500 кратному збільшенні, виявив велику кількість шкідливих мікроорганізмів (Николаевский Вестник, 1884: 3). Через більше ніж два десятиліття газета «Киевские новости» публікує позицію американського лікаря Томаса Дерлінгрона у необхідності оновлювати грошову масу паперових знаків що два роки, спираючись на життєздатність бактерій (Киевские новости, 1905: 4). 
Висновки. Дослідивши повідомлення із газет, що видавались на постійній регулярній основі в українських містах в другій пол. XIX - пер. чв. XX ст., ми змогла встановити такі основні типи повідомлень на шпальтах газетної преси:

- публікації про введення нових грошових знаків;

- повідомлення про курси обміну російських монет на іноземні;

- особливості обігу та ситуації на грошовому ринку;

- ціни на товари на ринках;

- повідомлення про підробки грошей;

- заходи влади щодо подолання фінансових складнощів: «монетного голоду», спекуляцій з грошима, тощо;

- про скупку старовинних монет, а також колекціонування та обман колекціонерів із старовинними монетами;

- професійні наукові нумізматичні дослідження та формування музейних нумізматичних зібрань;

- порядок обміну неплатіжних банкнот та ознаки їх придатності;

- інші свідчення, створені для викличення у читача різноманітних емоцій.

Широка різноманітність свідчень, що стосуються грошового обігу, поміщеної в газетних повідомленнях, дає підстави визначити високу ефективність використання інформації газетної періодики у вивченні обраної теми, визначаючи газети як ефективне та інформативне джерело.

\section{ДЖЕРЕЛА ТА ЛІТЕРАТУРА}

\section{Лimepamypa}

1. Kotsur V., Boiko-Gagarin A. Napoleon russian forged assignations in Naddniprianshchyna (over Dnipro land). East European historical bulletin. Issue 11. Drohobych, 2019. p. 66-77.

2. Бойко-Гагарин А.С. Фальсификация монет и банкнот в Польше до 1917 года по материалам украинской газетной периодики. Studia I Materialy «Forum Numizmatyczne, Pieniadz I Mennice». № 1. Bialystok, 2016. S. 103-109. 
3. Бойко-Гагарін А.С. Газетна періодика як джерело вивчення процесів фальшування монет та банкнот в кінці XIX - початку XX століття. Український нумізматичний щорічник. № 2. Переяслав-Хмельницький, 2018. С. 132-149.

4. Бойко-Гагарін А.С. Дореволюційні газети як джерело вивчення історії музейної справи в Україні. Науковий журнал «Краєзнавство». 2016. № 3/4 (96/97). Київ, 2016. С. 134-145.

5. Бойко-Гагарін А.С. Характеристика джерел вивчення фальшивих монет та банкнот в грошовому обігу України в імперську добу (1795-1917). Соціум. Документ. Комунікація. № 8. Серія: Історичні науки. Переяслав-Хмельницький: ФОП Домбровська Я.М. 2019. С. 55-75.

6. Коцур В.П. Історіографія українського скарбознавства. Український Нумізматичний Щорічник. № 1. Київ, 2017. С. 15-32.

7. Орлик В.М. Державні фінанси Російської імперії першої половини XIX ст.: стан та основні тенденції. Науковий вісник Ізмаїльського державного гуманітарного університету. Вип. 30. Ізмаїл, 2011. С. 96-108.

8. Орлик В.М. До питання методології досліджень проблем економічної історії Російської імперії. Проблеми історії України XIX - початку XX ст.: Зб. наук. пр. 2011. Вип. 18. Київ, 2011. C. 59-64.

9. Орлик В.М. Дожовтнева фінансово-правова література як джерело до вивчення проблем фінансової політики уряду Російської імперії кінця XVIII початку XX ст. Історія науки і біографістика. 2010. № 2.

10. Орлик В.М. Сгор Канкрін і фіскальна політика Російської імперії в Правобережній Україні в другій чверті XIX ст. Спеціальні історичні дисципліни: питання теорії та методики. 2006. № 13. C. 97-110.

11. Орлик В.М. Проблеми історії податкової політики Російської імперії в українському селі кінця XVIII - початку XX ст. в «аграрній» історіографії. Історія України. Маловідомі імена, події, факти. (Збірник статей). Випуск 27. Київ: Інститут історії НАН України, 2004. С. 224-239. 
12. Орлик В.М. Фонди міністерства фінансів у Російському державному історичному архіві. Студії з документознавства, архівознавства та спеціальних галузей історичної науки. Вип. 1. Кіровоград: КНТУ, 2011. С. 98-110.

13. Орлик В.М., Орлик С.В. Теоретико-методологічні та джерелознавчі проблеми економічної історії України. Універсум історії та археології. 2019. Том. 2 (27) Вип 2. Дніпро. C. 5-27.

14. Орлик С.В. Розмінні марки та казначейські знаки у грошовому обігу в Україні в період Першої світової війни. Спеціальні історичні дисципліни: питання теорії та методики. Збірка наукових праць. Число 26-27. С. 141-148.

15. Орлик С.В. Українське повітове місто і велика війна: продовольчі проблеми та ріст цін. Проблеми української історії. Вип. 23. Київ, 2015. С. 114-133.

\section{Газети}

16. А. Данилевскаго и Ко. Новороссийский Телеграф. № 3409. 7 июля. Одесса, 1886. С. 4.

17. Бон французского правительственного банка ценою в 5 франков. Одесские новости. № 9523. 17 ноября. Одесса, 1914. C. 2 .

18. В «Правит. Вестнике» напечатано Высочайшее повеление. Труд. № 112. 16 ноября. Киев, 1881. С. 3.

19. В Государственном Банке продаются по курсу серебяные рубли, изготовленные в память коронации. Екатеринославскийй исток. № 69. 24 июня. Екатеринослав, 1883. С. 3.

20. Жизнеспособность бактерий на монетах. Киевские новости. № 104. 13 мая. Киев, 1905. С. 4.

21. Исследование нумизматической коллекции и киевских курганов. Киевский Телеграф. № 90. 22 ноября. Киев, 1862. C. 569 .

22. К заметке о кладе. Житомирская минута. № 2. 27 декабря. Житомир, 1908. С. 2. 
23. Клад. Житомирская минута. № 1.2 декабря. Житомир, 1908. C. 2.

24. Кража старинных денег. Черниговское Слово. № 2472. 17 июля. Чернигов, 1915. С. 3.

25. Кто имеет старинные русские монеты. Кивеская Заря. № 7. 28 марта. Киев, 1906. С. 6.

26. Мелкая раменная монета. Вечерняя Газета. № 1057. 6 мая, Киев, 1916. С. 2.

27. Меняла. Вечерняя Газета. 28 марта. Киев, 1916. С. 4.

28. Многие губернские и уездные казначейства обратились недавно в министерство финансов. Николаевский Листок. № 133. 29 ноября. Николаев, 1883. С. 472-473.

29. Монетныя бактерии. Николаевский Вестник. № 360. 24 ноября. Николаев, 1884. С. 3.

30. Монеты из железа и олова. Вечерняя Газета. № 1068. 17 мая. Киев, 1916. С. 4.

31. Монеты. Фонды, акции и облигации. Елисаветградскийй Вестник. № 65. 22 марта. Елисаветград, 1891. С. 4.

32. Новые пятисотрублевые кредитные билеты. Южанин. № 277. 17 декабря. Николаев, 1898. С. 2.

33. Обмен сгоревших денег. Маленькие Одесские новости. № 1005. 1 июня. Одесса, 1916. С. 5.

34. Полукопейки. Маленькие Одесские новости. № 1072. 10 августа. Одесса, 1916. С. 4.

35. Такса на предметы первой необходимости, установленная Проскуровской Уездной Земскоц Управой. Земская Мысль. № 97. 25 апреля. Проскуров, 1915. С. 4.

36. Цены на продукты киевских рынков. Друг Народа. № 20. 17 мая. Киев, 1870. С. 320.

\section{REFERENCES}

1. Boiko-Haharin, A. S. (2018) Hazetna periodyka yak dzherelo vyvchennia protsesiv falshuvannia monet ta banknot $v$ kintsi XIXpochatku XX stolittia. [The newspapers periodicals as the source of study of the process of counterfeiting coins and banknotes during 
the late XIX - the early XX centuries]. Ukrainskyi numizmatychnyi shchorichnyk. 2. 132-149 [in Ukrainian].

2. Boiko-Haharin, A. S. (2019) Kharakterystyka dzherel vyvchennia falshyvykh monet ta banknot $v$ hroshovomu obihu Ukrainy v impersku dobu (1795-1917). [The characteristics of the sources of study of the counterfeit coins and banknotes in the monetary circulation of Ukraine during the imperial era (17951917)]. Sotsium. Dokument. Komunikatsiia. Seriia: Istorychni nauky. 8. 55-75. DOI: 10.31470/2518-7600-2019-8-55-75 [in Ukrainian].

3. Bojko-Gagarin, A. S. (2017) Fal'sifikacija monet $i$ banknot $v$ Pol'she do 1917 goda po materialam ukrainskoj gazetnoj periodiki [Falsification of coins and banknotes in Poland until 1917 according to the materials of the Ukrainian newspaper periodicals]. Abstract of papers: Forum Numizmatyczne, Pieniadz I Mennice [The numismatic forum, money and mints]. (pp. 103-109). Bialystok [in Russian].

4. Bojko-Haharin, A. S. (2016) Dorevoliutsijni hazety iak dzherelo vyvchennia istorii muzejnoi spravy v Ukraini [Prerevolution newspapers as the source of study of history of museology in Ukraine]. Kraieznavstvo, $3 / 4$ (96/97), 134-145 [in Ukrainian].

5. Kotsur, V. P. \& Boiko-Gagarin, A. S. (2019) Napoleon russian forged assignations in Naddniprianshchyna (over Dnipro land). East European historical bulletin. (11). 66-77. DOI: 10.24919/2519058x.11.170701 [in English].

6. Kotsur, V. P. (2017) Istoriohrafiia ukrainskoho skarboznavstva [The historiography of the Ukrainian treasurology]. Ukrainskyi Numizmatychnyi Shchorichnyk. 1. 15-33 [in Ukrainian].

7. Orlyk, S. V. (2015) Ukrains'ke povitove misto i velyka vijna: prodovol'chi problemy ta rist tsin [Ukrainian county town and the great war: the food problems and the rise of prices]. Problemy ukrains'koi istorii. (23), 114-133. Kyiv [in Ukrainian].

8. Orlyk, S. V. (2017) Rozminni marky ta kaznacheiski znaky u hroshovomu obihu $v$ Ukraini $v$ period Pershoi svitovoi viiny. 
[Currency Stamps and Treasury Marks in Ukraine during the First World War]. Spetsialni istorychni dystsypliny: pytannia teorii ta metodyky. (26-27). 141-148 [in Ukrainian].

9. Orlyk, V. M. \& Orlyk, S. V. (2019) Teoretyko-metodolohichni ta dzhereloznavchi problemy ekonomichnoi istorii Ukrainy. [Theoretical-methodological and source problems of economic history of Ukraine]. Universum istorii ta arkheolohii. [Universum of history and archeology]. Vol. 2 (27). Ed. 2. Dnipro. 5-27 [in Ukrainian].

10. Orlyk, V. M. (2004) Problemy istorii podatkovoi polityky Rosiiskoi imperii v ukrainskomu seli kintsia XVIII - pochatku XX st. $v$ «ahrarnii» istoriohrafii. [The problems of the history of the tax policy of the Russian empire in the Ukrainian suburb in the end of the XVIII - the beginning of the XX cent in the «agricultural» historiography]. Istoriia Ukrainy. Malovidomi imena, podii, fakty. [The history of Ukraine. Unknown names, events and facts]. (27). 224239 [in Ukrainian].

11. Orlyk, V. M. (2006). Yehor Kankrin i fiskalna polityka Rosiiskoi imperii v Pravoberezhnii Ukraini v druhii chverti XIX st. [Yegor Kankrin and the fiscal policy of the Russian Empire in Right-Bank Ukraine in the second quarter of the nineteenth century]. Spetsialni istorychni dystsypliny: pytannia teorii ta metodyky [Special Historical Disciplines: Theory and Methodology]. 13. Nats. akad. nauk Ukrainy, In-t istorii Ukrainy. 97-110 [in Ukrainian].

12. Orlyk, V. M. (2011) Fondy ministerstva finansiv u Rosiiskomu derzhavnomu istorychnomu arkhivi. [The funds of the Ministry of Finance in the Russian state historical archives]. Studii $z$ dokumentoznavstva, arkhivoznavstva ta spetsialnykh haluzei istorychnoi nauky. [The documentological, archival studies and the special branches of the historian csience]. (1). 98-110 [in Ukrainian].

13. Orlyk, V. M. (2011). Do pytannia metodolohii doslidzhen problem ekonomichnoi istorii Rosiiskoi imperii [On the question of the methodology of research on the problems of the economic 
history ofthe Russian Empire]. Problemy istorii Ukrainy XIX pochatku XXst. [The problems of the History of Ukraine of the 19th and early 20th centuries]. 18. 59-64 [in Ukrainian].

14. Orlyk, V. M. (2010). Dozhovtneva finansovo-pravova literatura yak dzherelo do vyvchennia problem finansovoi polityky uriadu Rosiiskoi imperii kintsia XVIII pochatku XX st. [The Prerevolutionary financial and legal literature as the source of studying of the problems of the financial policy of the government of Russian Empire in the late18th and early 20th century]. Istoriia nauky i biohrafistyka [History of Science and Biography studies]. (2) [in Ukrainian].

15. Orlyk, V. M. (2011). Derzhavni finansy Rosiiskoi imperii pershoi polovyny XIX st.: stan ta osnovni tendentsii. [The state finances of the Russian Empire in the first half of the XIX century: the condition and main tendencies]. Naukovyi visnyk Izmailskoho derzhavnoho humanitarnoho universytetu. [The science bulletin of the Izmail state university of humanities]. (30), 96-108 [in Ukrainian].

\section{АНОТАЦІЯ}

У статті проведено аналіз публікаџій зі сторінок дорадянської періодичної преси різних міст України з метою встановлення цінності газетних заміток як джерела та визначення ефективності їх використання у дослідженнях історії грошового обігу та фінансової політики російського царату в Україні з другої пол. ХІХ сm. до часу розвалу Російської імперії. У часи свого побутування газети були фактично єдиним ефективним та поширеним джерелом отримання актуальної інформації, слугували комунікативним інструментом між владою та населенням, надавали важливу інформацію з найрізноманітніших аспектів.

Нами проаналізовано та наведено найщікавіші приклади із публікацій газет, щуо стосуються різних аспектів грошового обігу. Дослідивши повідомлення із газет, щзо видавались на постійній регулярній основі в украӥнських містах в другій пол. 
XIX-пер. чв. ХХ ст., ми змогла встановити такі основні типи повідомлень на шпальтах газетної преси: публікації про введення нових грошових знаків; повідомлення про курси обміну російських монет на іноземні; особливості обігу та ситуації на грошовому ринку; ичіни на товари на ринках; повідомлення про підробки грошей; заходи влади щуодо подолання фінансових складношів: «монетного голоду», спекулячій з грошима, тощцо; про скупку старовинних монет, а також колекціонування та обман колекиіонерів із старовинними монетами; професійні наукові нумізматичні дослідження та формування музейних нумізматичних зібрань; порядок обміну неплатіжних банкнот та ознаки їх придатності; інші свідчення, створені для впливу на різноманітні емоції читача. Всі введені в науковий обіг газетні замітки суттєво розширюють наше уявлення про стан та особливості розвитку грошового обігу в Украӥні в імперську добу. Широка різноманітність свідчень, щзо стосуються грошового обігу, поміщеної в газетних повідомленнях, дає підстави визначити високу ефективність використання інформації газетної періодики у вивченні обраної теми, визначаючи газети як ефективне та інформативне джерело.

Ключові слова: Російська імперія, Наддніпрянська Україна, грошовий обіг, газетні видання, джерела вивчення, фінансова політика.

\section{АННОТАЦИЯ}

В статье приведен анализ публикащий со страниц досоветской периодической прессы разных городов Украины с целью определения иченности газетных заметок в качестве источника и оценки эффективности их использования в исследованиях истории денежного обращуения и российской финансовой политики в Украине со второй половинь XIX века до времени развала Российской империи. Во время своего бытования газеты были фрактически единственным эфрфективным и распространенным источником получения 
актуальной информации, служили коммуникативным инструментом между органами власти и населением, предоставляли важную информацию о самых разнообразных аспектах.

Нами проанализированы и представлены самые интересныле примеры из публикаџий газет, касающихся разных аспектов денежного обращуения. Исследовав сообщения из газет, которые издавались в период со второй пол. ХІХ по первую четверть ХX века, мы смогли установить такие основные типы сообщений: публикации о введении в обращуение новых денежных знаков; о курсы обмена российских монет на иностранные; особенности денежного обрашения и ситуации на денежном рынке; иены на товары и услуги на рынках; сообщение о появлении подделок; принятые властями меры по преодолению финансовых сложностей во время «монетного голода» спекуляцчии деньгами и т.д.; о скупке старинных монет, а также коллекиионирование и обман коллекционеров с древними монетами; профессиональные нумизматические научные исследования и формирование музейных собраний; иные сведения, опубликованные для вызова в читателя разнообразные эмоций. Все введенные в научный оборот материалы газетных заметок существенно расширяют наше представление о состоянии и особенности развития денежного обращуения в Украине в империалистическую эпоху. Широкое разнообразие размещуенных в газетах сведений дают возможность определить газеты как эффективный источник в исследовании истории денежного обращуения в Украине во второй половине XIX-начале XX века.

Ключевые слова: Российская империя, Надднепрянская Украина, денежное обращуение, газетные публикации, источники изучения, финансовая политика. 


\section{Ілютрації}

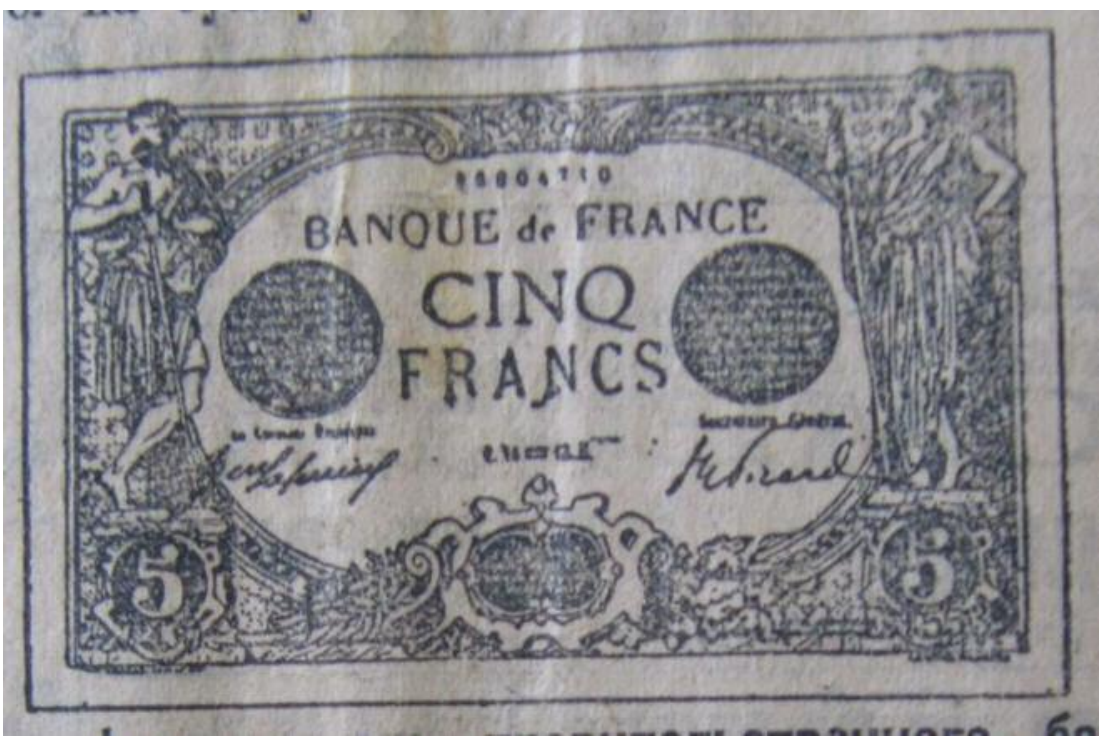

Рис. 1. Абрис нової французьської банкноти номіналом 5 франків з повідомлення газети «Одесские Новости» за 17 листопада 1914 p. 


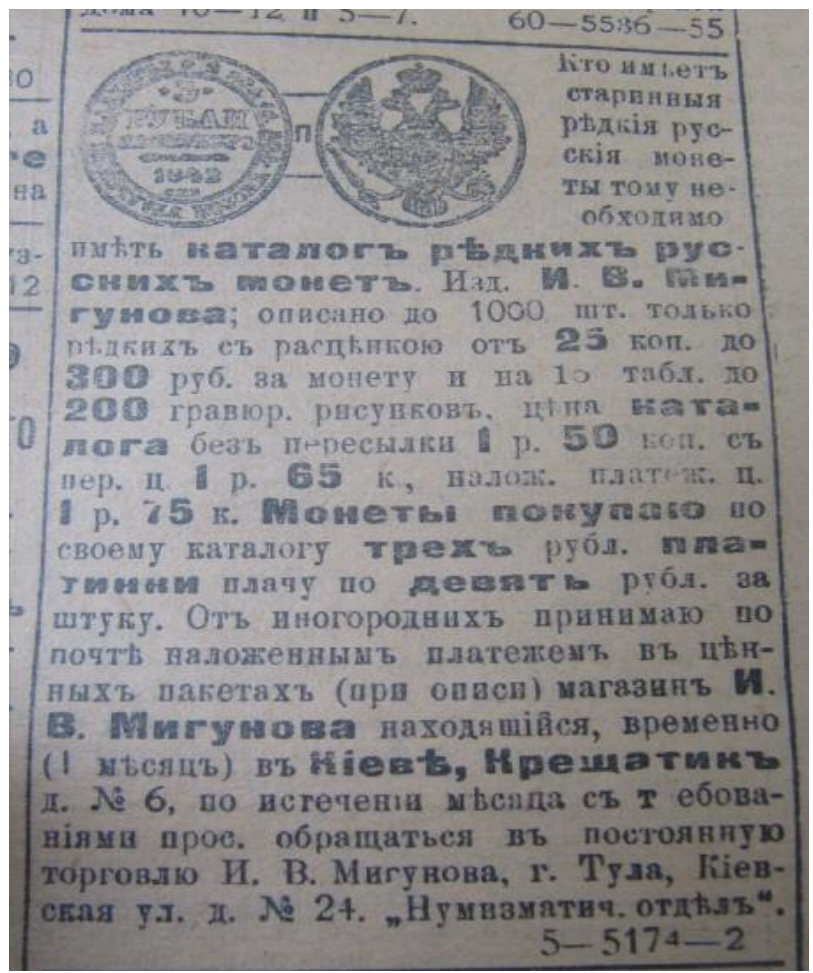

Рис. 2. Повідомлення магазину І.В. Мігунова про скупку старовинних монет. Газета «Киевская Заря», 1906 р. 